\title{
Selective recovery of chromium ions from waste tannery solution for preparation of chromium oxide nanoparticles
}

\author{
S. M. El-Sheikh ${ }^{1} \cdot$ M. A. Rabah ${ }^{2}$
}

Received: 28 February 2013/Revised: 28 January 2015/ Accepted: 17 March 2015/Published online: 9 April 2015

(C) Islamic Azad University (IAU) 2015

\begin{abstract}
This investigation seeks to reduce the environmental impact of the tanning process by recovering $\mathrm{Ca}$ and $\mathrm{Cr}$ from tannery waste solution. The treatment process reduces both the amount of $\mathrm{Cr}$ discharged to the environment and the amount of raw $\mathrm{Cr}$ extracted from natural resources. The procedure was based on the selective separation of $\mathrm{Ca}$ ions from the waste solution as $\mathrm{Ca}$ oxalate, prior to the recovery of $\mathrm{Cr}$ as the hydroxide precipitate at $\mathrm{pH}$ 6.5. The dried $\mathrm{Cr}$ hydroxide cake was then subjected to heating (heating rate $0.5{ }^{\circ} \mathrm{C} \mathrm{min}^{-1}$ ) at different temperatures up to $500{ }^{\circ} \mathrm{C}$ to produce $\mathrm{Cr}$ oxide nanoparticles. The physicochemical characteristics of the nanoparticles were investigated using X-ray diffraction, Fourier transform infrared, scanning electron microscopy, transmission electron microscopy, surface area measurement and thermal analysis. Results revealed that heating of the treated $\mathrm{Cr}$ hydroxide at $300{ }^{\circ} \mathrm{C}$ yielded amorphous $\mathrm{Cr}$ oxide, while with heating at $400{ }^{\circ} \mathrm{C}$, the $\mathrm{Cr}$ oxide started to crystallize to hexavalent, trivalent and divalent $\mathrm{Cr}$ species. At $500{ }^{\circ} \mathrm{C}$, a pure phase consisting of trivalent $\mathrm{Cr}$ oxide nanoparticles was formed that contained traces of hexavalent Cr. A mechanism for the formation of the different forms of $\mathrm{Cr}$ oxide was proposed and confirmed by XRD.
\end{abstract}

S. M. El-Sheikh

selsheikh2001@gmail.com

1 Nanostructured Materials Division, Advanced Materials Department, Central Metallurgical R and D Institute (CMRDI), P.O. Box 78, Helwan, Cairo 11421, Egypt

2 Electrochemical and Chemical Treatment Laboratory, Minerals Department, Central Metallurgical R and D Institute (CMRDI), P.O. Box 78, Helwan, Cairo 11421, Egypt
Keywords Nanomaterials - Secondary resources · Selective separation Chromium oxide nanoparticles

\section{Introduction}

In leather tanning, various salts and lime are used in the early stages of the process. Chromium sulfate is widely used as a tanning agent. Traditional leather tanning operations discharge about $42 \%$ of the input chromium (Cr) as a waste solution (Ludvik 2004). High efficiency in the tanning process and recycling of the $\mathrm{Cr}$ cannot completely eliminate $\mathrm{Cr}$ from the wastewater, given that there is usually significant discharge in post-tanning processes (IULTCS 2014). Chromium exists in different chemical forms, most commonly the trivalent $[\mathrm{Cr}(\mathrm{III})]$ and hexavalent $[\mathrm{Cr}(\mathrm{VI})]$ forms. The trivalent form of $\mathrm{Cr}$ is non-toxic and relatively immobile in nature, whereas hexavalent $\mathrm{Cr}$ is readily soluble in water, highly toxic and mobile, and is known to be toxic with potential carcinogenic effects (Gebrehawaria et al. 2014; Jiao et al. 2014). Recovery of $\mathrm{Cr}$ from waste tannery solutions has been studied using various physicochemical processes, such as oxidation/reduction, precipitation/filtration, coagulation, ion exchange, adsorption and membrane separation. Kanagaraj et al. (2008) reported that the water extract from the bark of the tree species, Acacia mollissima, was used for recovery of $\mathrm{Cr}$ from tannery waste water at different $\mathrm{pH}$ values $(7,8$ and 9). The recovered $\mathrm{Cr}$ was reused for tanning pelts. Moreover, plant-derived biosurfactant quillaja bark saponin was applied to a dewatered tannery sludge for $\mathrm{Cr}$ recovery, and a comparative assessment with an $\mathrm{H}_{2} \mathrm{O}_{2}$ oxidative treatment method was undertaken (Kilic et al. 2011). The $\mathrm{H}_{2} \mathrm{O}_{2}$ treatment, which involved oxidation of $\mathrm{Cr}(\mathrm{III})-\mathrm{Cr}(\mathrm{VI})$ and extraction with sulfuric acid solution at 
$\mathrm{pH} 2$, enabled the extraction of $70 \%$ of $\mathrm{Cr}$ within $4 \mathrm{~h}$ at room temperature (Kilic et al. 2011). Furthermore, Tahir et al. (2007) reported that more than $99 \%$ of $\mathrm{Cr}$ (III) from tannery wastewater (3 M sulfuric acid) was recovered by adsorption onto bentonite clay. In addition, batch and column experiments using biological waste material (sawdust, rice husk, coir pith and charcoal) and a naturally occurring mineral (vermiculite) have been tested for their effectiveness in removing $\mathrm{Cr}$ from tannery effluent. The biosorbent and mineral vermiculite in column format were found to be very effective in removing $\mathrm{Cr}$ from tannery effluent (Sumathi et al. 2005). Meanwhile, Ortega et al. used a nanofiltration membrane to separate $\mathrm{NaCl}$ and $\mathrm{Cr}_{2}\left(\mathrm{SO}_{4}\right)_{3} \cdot 5 \mathrm{H}_{2} \mathrm{O}$ from tannery effluents. These workers demonstrated that $\mathrm{Cr}$ (III) retention was dependent on the membrane type used, the $\mathrm{Cr}^{3+}$ concentrations (15.2 and $30.3 \mathrm{molm}^{-3}$ ) and the operating conditions (Ortega et al. 2005). Additional methods for recovery of $\mathrm{Cr}$ from tannery waste solutions have been proposed, including separation of $\mathrm{Cr}$ (III) by oxidation to $\mathrm{Cr}$ (VI) with sulfuric acid (Macchi et al. 1991) and bio-leaching using a novel mixture of ironand sulfur-oxidizing bacteria (Zhou et al. 2006), as well as ion exchange (Kabir et al. 2008). The main drawbacks of these methods are operational difficulties, excessive use of chemicals and long processing times. Recently, Abreu et al. (2009) reported that the $\mathrm{Cr}$ oxide extracted from $\mathrm{Cr}$-rich waste sludge could serve as a ceramic pigment in a conventional glaze composition usually used in the ceramic tile industry. Moreover, $\mathrm{Cr}$ oxide, synthesized by thermal decomposition of solid precursors, was evaluated as a catalyst for ammonia decomposition (Zhu et al. 2008). ElSheikh et al. (2009a, b) and El-Sheikh and Rabbah (2013) reported that the amorphous phase of $\mathrm{Cr}_{2} \mathrm{O}_{3}$, which formed at room temperature, was transformed to the crystalline phase by heat treatment at about $400{ }^{\circ} \mathrm{C}$.

A coagulating agent is typically used for solids separation in wastewater treatment, and aluminum ( $\mathrm{Al}$ ) salts such as $\mathrm{Al}_{2}\left(\mathrm{SO}_{4}\right)_{3}$ and $\mathrm{AlCl}_{3}$ are generally used for this purpose. In solution, the $\mathrm{Al}$ ion hydrolyzes and generates some ionic monomer species like $\mathrm{Al}(\mathrm{OH})_{4}^{-}, \mathrm{Al}(\mathrm{OH})_{2}^{+}$and $\mathrm{Al}(\mathrm{OH})^{2+}$, and also polymeric species like $\mathrm{Al}_{13} \mathrm{O}_{4}(\mathrm{OH})_{24}^{7+}$, as well as $\mathrm{Al}(\mathrm{OH})_{3}$. The interaction of these species with wastewater contaminants leads to the aggregation of colloidal particles, which later precipitate (Song et al. 2004). The precipitated portion, defined as primary sludge, is then separated from the clear effluent. This process is clearly efficient for removing wastewater contaminants and, as noted by Cañizares et al. (2006), is basically a simple physicochemical process of phase transfer.

To date, no studies have been reported on the selective removal of calcium $(\mathrm{Ca})$ ions before precipitation of $\mathrm{Cr}$ ions from industrial waste tannery solutions. In this study, an investigation has been made to recover $\mathrm{Cr}$ from spent tannery liquor by a simple separation technique based on precipitation. A key research objective was to separate $\mathrm{Ca}$ and $\mathrm{Cr}$ before preparation of trivalent $\mathrm{Cr}$ oxide nanoparticles. A further objective was to clean the wastewater prior to recycling and reuse in the tanning process.

\section{Materials and methods}

\section{Reagents and materials}

Approximately $2 \mathrm{~m}^{3}$ of waste tannery solution was supplied by a tannery plant located at El-Basaten in Cairo. Analytical grade oxalic acid (99.8\%, Brixworth, Northampton, UK), ammonium chloride (99.7\%, RPS Chemical Co. Ltd, Lutterworth, UK), ammonium hydroxide (25\%, ADWIC, Cairo, Egypt), petroleum ether and ethyl ether (99.8\% ADWIC, Cairo, Egypt) were used without further purification. Doubly distilled water was used for chemical analysis and the rinsing and washing of laboratory ware.

\section{Methods}

The waste tannery solution was filtered using a cloth silk screen (Nr. 1000, Switzerland). The solids collected on the filter were discarded. A sample of the filtrate was dried in a laboratory oven maintained at $105{ }^{\circ} \mathrm{C}$. Fifteen grams of the dried solid was ground and analyzed by X-ray fluorescence (XRF). A further portion of filtrate was stirred with a mixture of one part petroleum ether and one part ethyl ether for $6 \mathrm{~h}$ at room temperature to attain partial removal of the soluble fats. The degreased solution was separated from the organic solvents with a separating funnel. Organic solvents were recycled. Calcium ions were removed from a sample of the waste solution by precipitation as $\mathrm{Ca}$ oxalate at room temperature and $70{ }^{\circ} \mathrm{C}$ over $1 \mathrm{~h}$. The filtrate was then taken for further processing. Precipitation of $\mathrm{Cr}$ as the hydroxide was carried out by the addition of a few milliliters of ammonia solution preceded by ammonium chloride as a buffer salt. Addition of ammonia was carried out dropwise to attain a $\mathrm{pH}$ value of 6.5 compared with $\mathrm{pH} 3.3$ for the original waste solution. The precipitate was dried at $105{ }^{\circ} \mathrm{C}$. The dried precipitate was washed with hot water several times to remove sodium chloride. The precipitate was then heated at various temperatures between 300 and $500{ }^{\circ} \mathrm{C}$ for $2 \mathrm{~h}$, using a clean porcelain crucible. Heating was performed in a muffle furnace (type Nabertherm, Netherlands), equipped with an automatic temperature controller. Temperature was increased at a rate of $0.5{ }^{\circ} \mathrm{C} \mathrm{min}{ }^{-1}$, starting from room temperature. Throughout the process of metals separation, the wastewater was purified using a $0.005 \%$ solution of polyacrylamide (PA) 


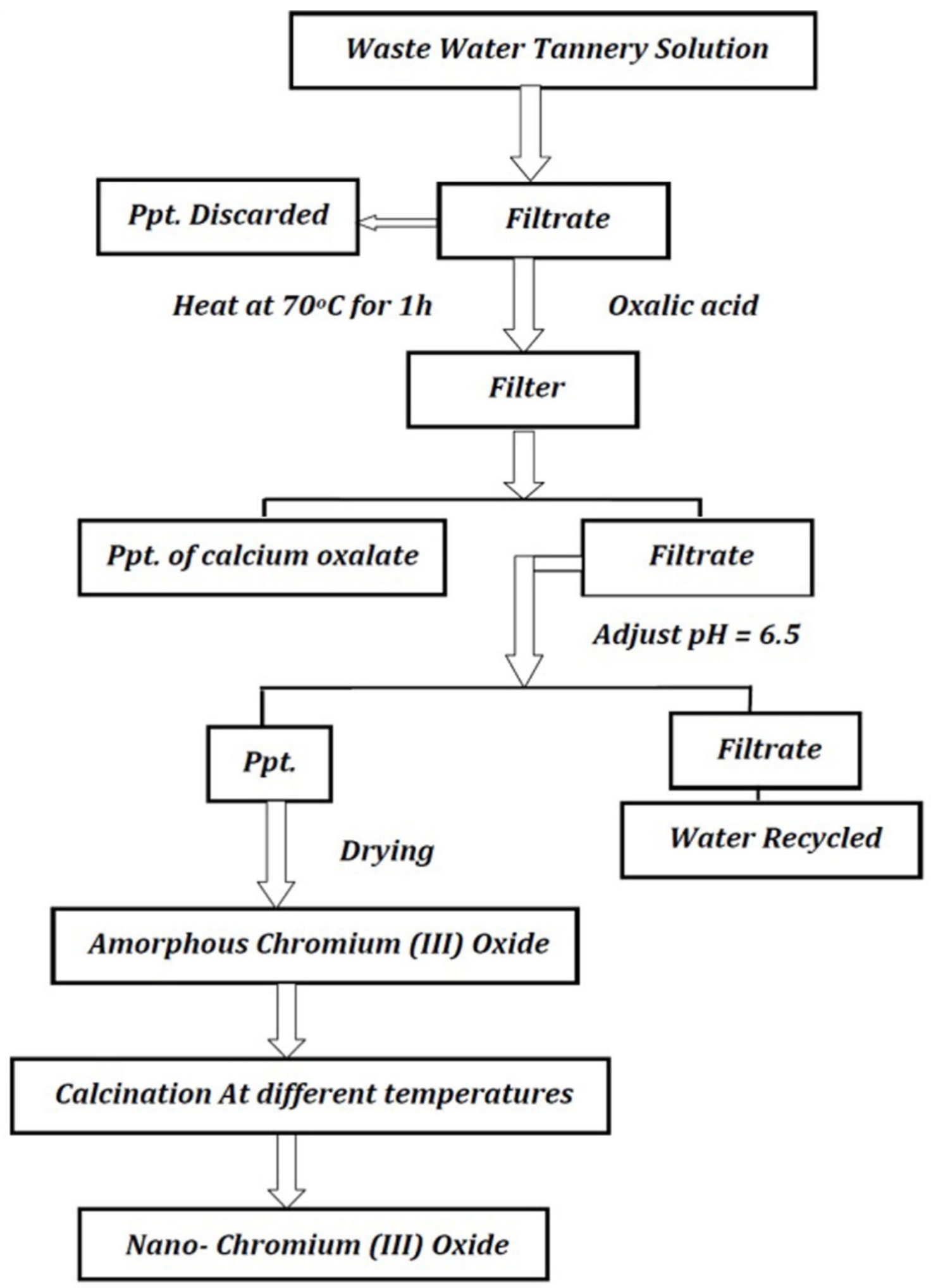

Fig. 1 Schematic diagram for synthesis of chromium oxide nanoparticles from tannery waste solution 
(100 Cyanamid, France), as coagulant. The filtered water was suitable for reuse. Figure 1 shows a schematic diagram of the process followed for the preparation of $\mathrm{Cr}$ oxide from the waste solution.

\section{Nanoparticle characterization}

\section{Instrumentation}

A laser ablation system (UP213 New Wave) interfaced to an inductively coupled plasma mass spectrometer [ICPMS, Varian (Brucker), LA, USA] was used for trace analysis of the fine metal powder. A sequential WD-XRF (Axios, Panalytical 2005, Almelo, Netherlands) was used to determine major and minor components (Beckhoff et al. 2006) in the powder. Phase identification, purity, relative crystallinity and crystal size measurements on the prepared compounds were performed at room temperature with the aid of XRD (Bruker AXIS D8, Germany) with $\mathrm{Cu}-\mathrm{K}_{\alpha}$ $(\lambda=1.5406 \AA$, radiation and secondary monochromator $2 \theta$ in the range of $20^{\circ}-80^{\circ}$ ). The relative crystallinity and crystal size were calculated via the Scherrer equation (Scherrer 1918; Patterson 1939). Transmission electron microscopy (TEM, JEOL-JEM-1230, Tokyo, Japan) was used to determine the microstructure of the $\mathrm{Cr}$ oxide samples (Williams et al. 1996). Infrared absorption spectroscopy (IR) was performed with a JASCO 3600 IR spectrophotometer (Tokyo, Japan). A scanning electron microscope (SEM, JEOL model JSM-5410, Tokyo, Japan) was used to investigate the microstructure of the prepared material end product.

\section{Specific surface area}

The specific surface area, pore volume and pore size distribution of samples heated at $400{ }^{\circ} \mathrm{C}$ were measured using the nitrogen adsorption-desorption technique (Quantachrome, model NOVA 2000). The sample was degassed at $373 \mathrm{~K}$ for $24 \mathrm{~h}$ before measurement at $77 \mathrm{~K}$. The adsorbed gas volume was taken as $\mathrm{cm}^{3}$ per $\mathrm{g}$ at STP. The pore size was calculated from the desorption isotherms based on the Barrett, Joyner and Halenda (BJH) method (Terzyk et al. 2007). The BJH method is a procedure for calculating pore size distributions from experimental isotherms using the Kelvin model of pore filling and applies only to the mesopore and small macropore size ranges. The specific surface area was calculated using the BrunauerEmmett-Teller equation (BET) (Brunauer et al. 1938).

\section{Thermal analysis}

Thermogravimetric (TGA) and differential thermogravimetric (DTA) analyses were performed by heating the sample at a rate of $10{ }^{\circ} \mathrm{C} / \mathrm{min}$ using a Shimadzu-50H TGA analyzer (Tokyo, Japan) in an air atmosphere (Coats et al. 1963).

\section{Results and discussion}

\section{Effect of $\mathrm{pH}$ on $\mathrm{Cr}$ precipitation}

Measurement of sample $\mathrm{pH}$ indicated that the waste solution was slightly acidic with a $\mathrm{pH}$ of 3.3. Figure 2 shows the effect of $\mathrm{pH}$ on the precipitation of $\mathrm{Cr}$ hydroxide. With an increase in $\mathrm{pH}$ from 3.3 to 10 , two plateau levels are evident. The first plateau at $\mathrm{pH} 6.5$ represents the precipitation of $\mathrm{Cr}$ hydroxide, while the second plateau at $\mathrm{pH}$ 8.5 is assigned to the precipitation of $\mathrm{Mg}$ hydroxide.

\section{The effect of temperature on weight loss}

Figure 3 shows the weight loss from the gel-like precipitate as a result of heating at 80 and $100{ }^{\circ} \mathrm{C}$. It is seen that with an increase in the time of heating from 80 and $100{ }^{\circ} \mathrm{C}$ there is a corresponding increase in the weight loss. It is suggested that for the early period of heating, the weight loss was due to the removal of water present in the gel. After $8 \mathrm{~h}$ of heating at $100{ }^{\circ} \mathrm{C}$, the weight loss amounted to $65 \%$. With further heating for $24 \mathrm{~h}$, the weight loss approached a relatively constant value of $92 \%$, yielding a salt composition of $8 \% \mathrm{w} / \mathrm{w}$ (dry weight basis).

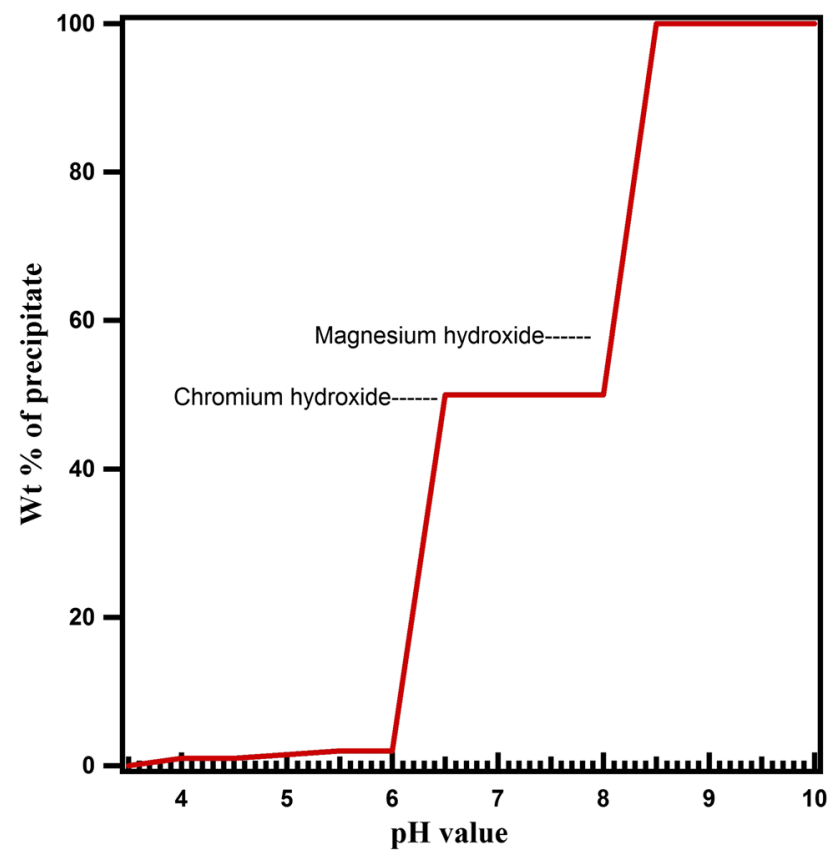

Fig. 2 Effect of $\mathrm{pH}$ on precipitation of chromium and magnesium hydroxide (El-Sheikh and Rabbah 2013) 


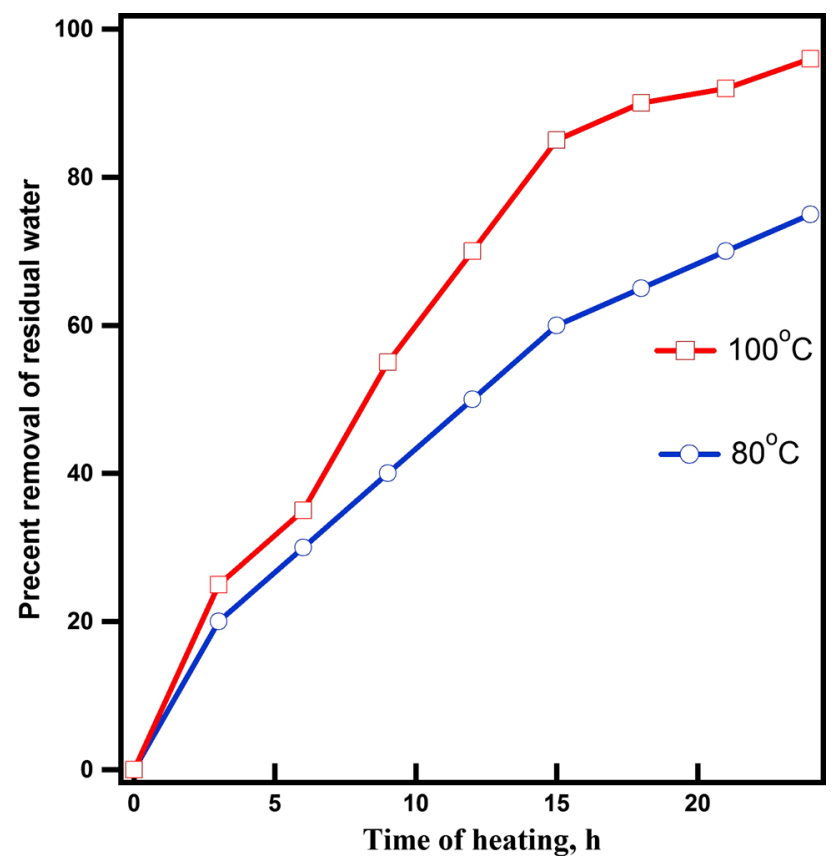

Fig. 3 Weight loss for $\mathrm{Cr}(\mathrm{OH})_{3}$ gel as affected by temperature and time (El-Sheikh and Rabbah 2013)

Table 1 Solids present in the tannery waste solution as revealed by XRF (El-Sheikh and Rabbah 2013)

\begin{tabular}{llll}
\hline Compound & Weight $\%$ & Compound & wt\% \\
\hline $\mathrm{Na}$ as $\mathrm{Na}_{2} \mathrm{O}$ & 29.122 & $\mathrm{NaCl}$ & 74.958 \\
$\mathrm{Mg}$ as $\mathrm{MgO}$ & 3.292 & $\mathrm{MgSO}_{4}$ & 9.820 \\
$\mathrm{Ca}$ as $\mathrm{CaO}$ & 2.798 & $\mathrm{Ca}(\mathrm{OH})_{2}$ & 3.697 \\
$\mathrm{Cr}$ as $\mathrm{Cr}_{2} \mathrm{O}_{3}$ & 3.125 & $\mathrm{Cr}_{2}\left(\mathrm{SO}_{4}\right)_{3}$ & 9.007 \\
$\mathrm{~K}$ as $\mathrm{K}_{2} \mathrm{O}$ & 0.920 & $\mathrm{KCl}$ & 1.096 \\
$\mathrm{Al}$ as $\mathrm{Al}_{2} \mathrm{O}_{3}$ & 0.094 & $\mathrm{AlSO}_{4}$ & 0.138 \\
$\mathrm{Si}$ as $\mathrm{SiO}_{2}$ & 0.259 & $\mathrm{SiO}_{2}$ & 0.259 \\
$\mathrm{P}$ as $\mathrm{P}_{2} \mathrm{O}_{5}$ & 0.034 & $\mathrm{P}_{2} \mathrm{O}_{5}$ & 0.166 \\
$\mathrm{Fe}$ as $\mathrm{Fe}_{2} \mathrm{O}_{3}$ & 0.058 & $\mathrm{Fe}_{2} \mathrm{O}_{3}$ & 0.058 \\
$\mathrm{Zn}$ as $\mathrm{ZnO}$ & 0.019 & $\mathrm{ZnSO}$ & 0.042 \\
$\mathrm{Sr}$ as $\mathrm{SrO}_{\mathrm{Cl}}$ & 0.020 & $\mathrm{SrO}_{4}$ & 0.020 \\
$\mathrm{SO}$ & 38.62 & others & 0.739 \\
$\mathrm{Br}$ & 21.562 & & \\
& 0.077 & & $100 \%$ \\
\hline
\end{tabular}

\section{XRF analysis}

Table 1 shows the XRF data for the inorganic components derived from the tannery waste solution. Sodium chloride is the major component $(75.0 \mathrm{wt} \%)$ of the powdered precipitate. Chromium sulfate $(9.00 \%), \mathrm{Mg}$ sulfate $(9.82 \%)$ and $\mathrm{Ca}$ hydroxide $(3.70 \mathrm{wt} \%$ ) were also measured. Other salts were present at the trace level.

\section{XRD of Ca oxalate}

Figure 4 shows the XRD patterns for $\mathrm{Ca}$ oxalate and $\mathrm{Ca}$ sulfate precipitated by addition of oxalic acid at room temperature and at $70{ }^{\circ} \mathrm{C}$, respectively. Sharp XRD peaks for $\mathrm{Ca}$ oxalate were obtained at room temperature. The peaks were prominent and consisted of two different phases of Ca oxalate: The first phase (141) was tetragonal weddellite (JCPDS card no. 75-1314) and the other phase (040) was monoclinic weddellite (JCPDS card no. 75-1313). In the case of $\mathrm{Ca}$ sulfate, this was formed as a result of the reaction of sulfate ions, present in the filtrate, with the oxalate salt to give a thermally stable compound (JCPDS card no. 74-1433).

\section{XRD of Cr oxide}

Figure 5 shows the XRD patterns of the $\mathrm{Cr}_{2} \mathrm{O}_{3}$ nanoparticles produced by precipitating $\mathrm{Cr}$ hydroxide at $\mathrm{pH} 6.5$ and heating at various temperatures $\left(300,400\right.$ and $\left.500{ }^{\circ} \mathrm{C}\right)$. The soaking time was $3 \mathrm{~h}$ with a heating rate of $0.5^{\circ} \mathrm{C} / \mathrm{min}$. Spectra are presented as multiple plots. It can be seen that for the sample heated at $300{ }^{\circ} \mathrm{C}, \mathrm{Cr}$ has an amorphous phase. The XRD pattern of the powdered sample heated at $400{ }^{\circ} \mathrm{C}$ shows several prominent XRD peaks. The material consisted of two different phases of $\mathrm{Cr}$ oxide. One was $\mathrm{Cr}_{2} \mathrm{O}_{3}$ (JCPDS card no. 82-1484) and the other phase was $\mathrm{CrO}_{3}$ (JCPDS card no. 01-0622). With further increases in temperature up to $500{ }^{\circ} \mathrm{C}$, the stable crystalline hexagonal (rhombohedral) form of the $\mathrm{Cr}_{2} \mathrm{O}_{3}$ phase developed, the material containing traces of $\mathrm{CrO}_{3}$. Peak intensities slightly increased with increasing calcination temperature. These findings are in good agreement with published studies (Gupta et al. 2014; Colmenares et al. 2014).

\section{Crystallite size of $\mathrm{Cr}$ oxide measured by XRD}

Calculation of the crystallite size from the XRD data using the Scherrer equation revealed that the crystallite size increased with increasing temperature. For example, the crystallite size increased from 60 to $80 \mathrm{~nm}$ as the calcination temperature increased from 400 to $500{ }^{\circ} \mathrm{C}$. This phenomenon is attributed to the fact that increasing temperatures confer an enhanced tendency for particle grain growth.

\section{FT-IR spectra}

The IR spectra of $\mathrm{Cr}_{2} \mathrm{O}_{3}$ powders obtained from precipitated $\mathrm{Cr}$ hydroxide at $\mathrm{pH} 6.5$ and for heating at various temperatures $\left(300,400\right.$ and $\left.500{ }^{\circ} \mathrm{C}\right)$ are presented in Fig. 6 . The spectra display bands at 404-414, 563-566, 623, 880, $1097-1145$ and $1619 \mathrm{~cm}^{-1}$ as well as a broad band 


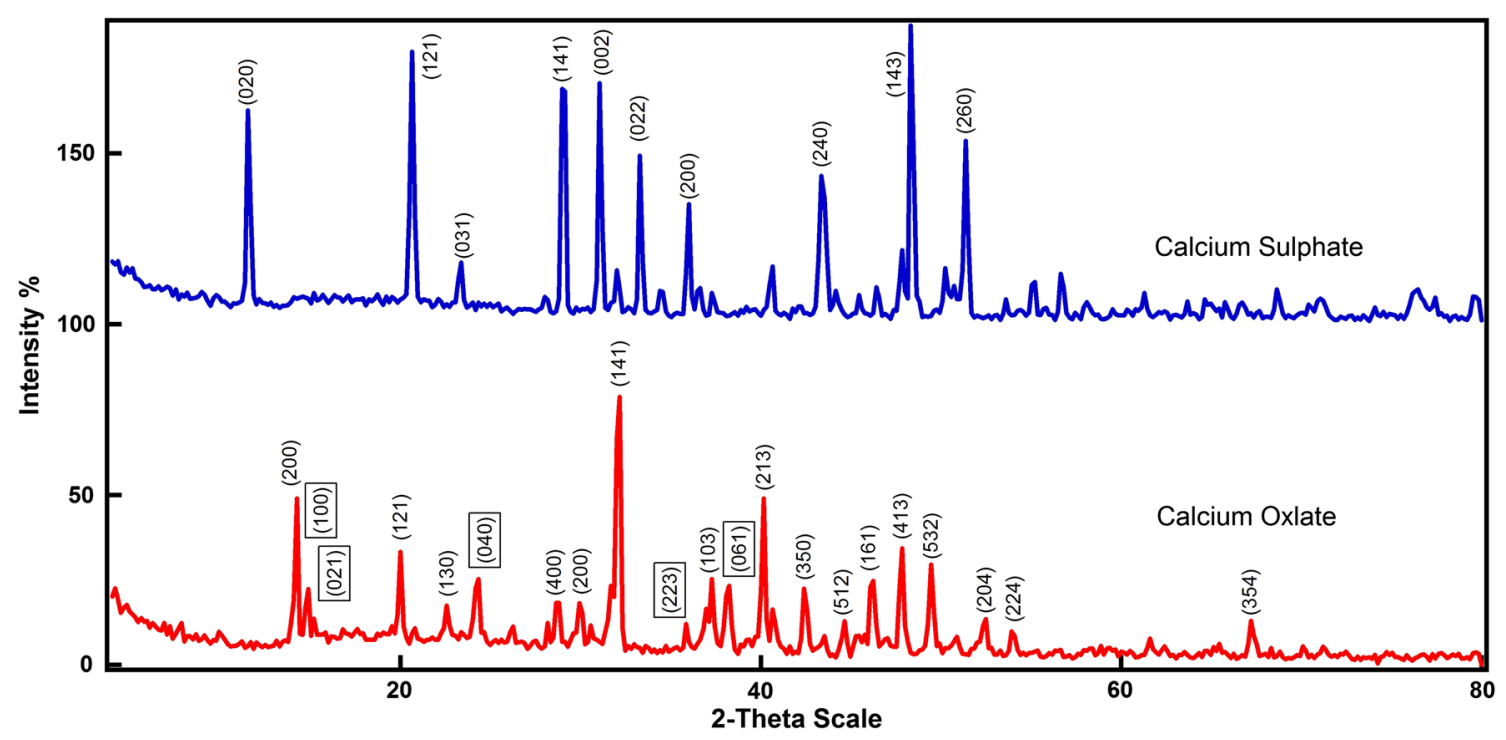

Fig. 4 XRD pattern of calcium oxalate and sulfate precipitated by the addition of oxalic acid at room temperature (RT) and at $70{ }^{\circ} \mathrm{C}$, respectively

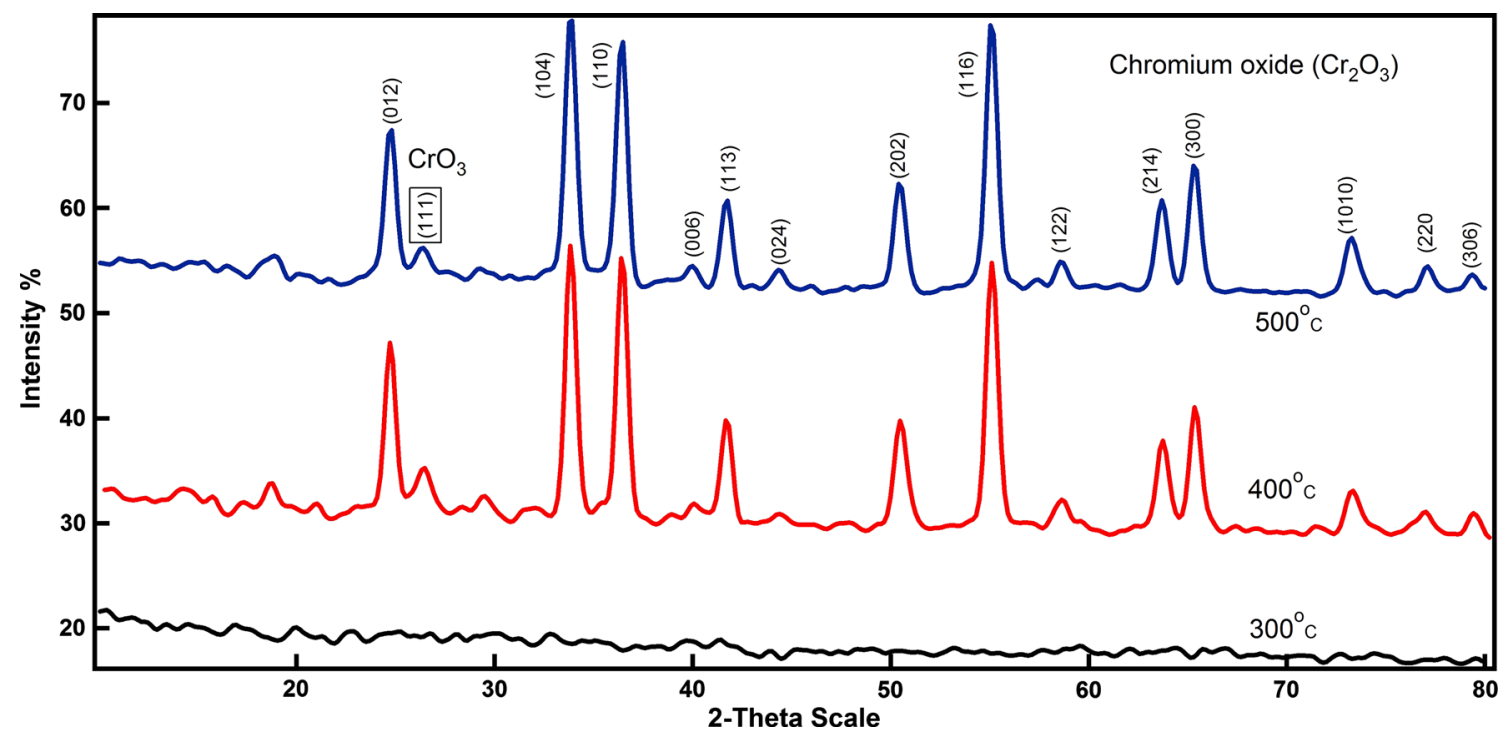

Fig. 5 XRD patterns for $\mathrm{Cr}_{2} \mathrm{O}_{3}$ nanoparticles after heating chromium hydroxide samples (pH 6.5) to various temperatures $\left(300,400\right.$ and $\left.500{ }^{\circ} \mathrm{C}\right)$

between 2800 and $3366 \mathrm{~cm}^{-1}$. It can be deduced that the appearance of the latter band is ascribed to the surface $-(\mathrm{OH})$ stretching groups resulting from a dissociation of chemisorbed and non-dissociated water molecules (ElSheikh et al. 2009a; Lime et al. 2006). The weak absorption bands appearing at 1619 and the strong peak at $1097-1145 \mathrm{~cm}^{-1}$ are attributed to hydroxyl groups associated with $\mathrm{Cr}^{3+}$ ions. The large band in the range $400-650 \mathrm{~cm}^{-1}$ may be assigned to the bonds between $\mathrm{Cr}$ and oxygen atoms. The strong sharp peak at $563-566 \mathrm{~cm}^{-1}$ was attributed to hexagonal $\mathrm{Cr}_{2} \mathrm{O}_{3}$ and corresponded to the characteristic vibrational mode of symmetric octahedral $\mathrm{CrO}_{6}$ of $\mathrm{Cr}_{2} \mathrm{O}_{6}$. The strong sharp peak that appeared at $880 \mathrm{~cm}^{-1}$ was ascribed to $\mathrm{Cr}_{2} \mathrm{O}_{3}$ (El-Sheikh et al. 2009a; Lime et al. 2006). The FT-IR analysis with sample heated at $300{ }^{\circ} \mathrm{C}$ revealed a prominent broadband in the region $3688-2850 \mathrm{~cm}^{-1}$ and bands at 544, 755, 943 and $1104 \mathrm{~cm}^{-1}$. The band at $943 \mathrm{~cm}^{-1}$ gradually disappeared with increase in temperature. This result is consistent with the transition of amorphous $\mathrm{Cr}_{2} \mathrm{O}_{3+\mathrm{x}}$ to crystalline $\mathrm{Cr}_{2} \mathrm{O}_{3}$ (El-Sheikh et al. 2009a; Lime et al. 2006). This conclusion is also consistent with the XRD data. 


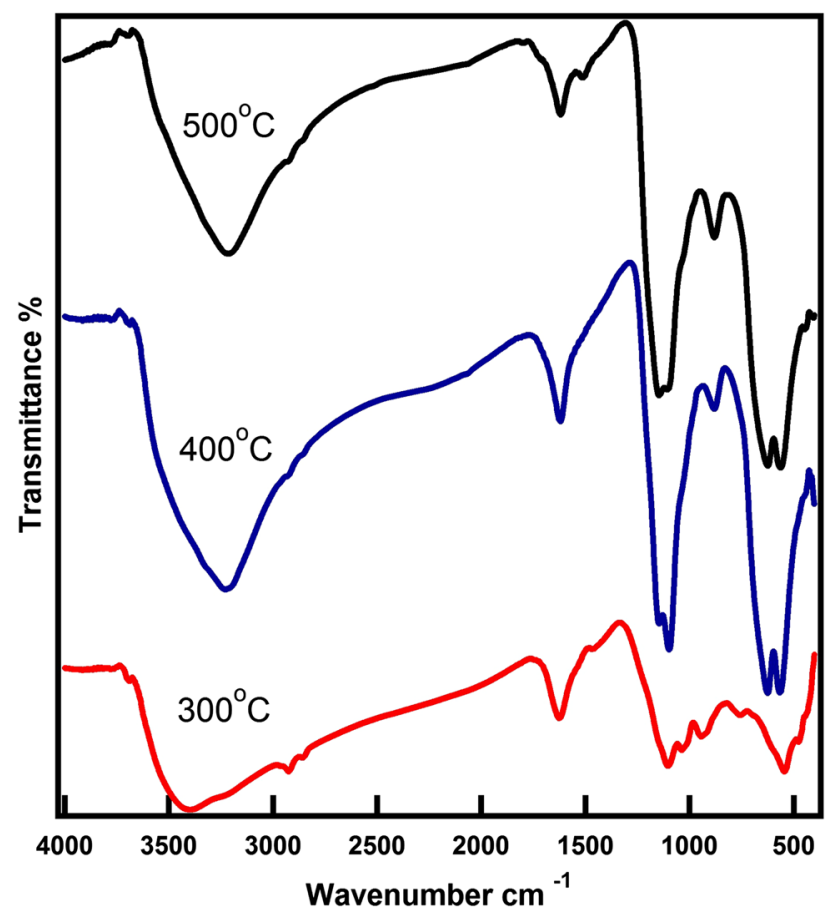

Fig. 6 FT-IR spectra $\left(400-4000 \mathrm{~cm}^{-1}\right)$ of $\mathrm{Cr}_{2} \mathrm{O}_{3}$ nanoparticles precipitated at $\mathrm{pH} 6.5$ and heated at different temperatures

\section{Morphology of $\mathrm{Cr}$ oxide}

The SEM image of the $\mathrm{Cr}$ oxide powder after heating at $500{ }^{\circ} \mathrm{C}$ is presented in Fig. 7a. It can be seen that the sample consisted of spherical particles uniformly distributed. The TEM images of the Cr oxide sample, after heating at 400 and $500{ }^{\circ} \mathrm{C}$ as shown in Fig. 7 b-e, reveal particles of diameter $80-400 \mathrm{~nm}$. Additionally, Fig. 7c clearly shows that the microsphere structure is an assemblage of smaller nanoparticles. Figure $7 \mathrm{e}$, d indicates that $\mathrm{Cr}_{2} \mathrm{O}_{3}$ particles have a mesospheric structure after being heated at $500{ }^{\circ} \mathrm{C}$. This is attributed to the fact that small nanoparticles possess a large specific surface area and would be active catalytic centers able to form microspheres. Meanwhile, the average crystallite size increased with an increase in the heating temperatures from 400 to $500{ }^{\circ} \mathrm{C}$.

\section{Specific surface area}

Results for the specific surface area of $\mathrm{Cr}$ oxide and the pore diameter for a sample heated at $400{ }^{\circ} \mathrm{C}$ are presented in Fig. 8a and b. It is seen that the $\mathrm{Cr}_{2} \mathrm{O}_{3}$ nanopowder has a surface area of $30 \mathrm{~m}^{2} \mathrm{~g}^{-1}$. The isotherm type for the $\mathrm{Cr}$ oxide is type IV according to the IUPAC classification. This category exhibits the characteristic hysteresis loop of mesoporous materials (El-Sheikh et al. 487, 2009b) and confirms that nanosize $\mathrm{Cr}$ oxide obtained by thermal treatment has a mesoporous structure. This is consistent with the fully dispersed collagen proteins in the gel precipitate undergoing thermal decomposition with the empty space in effect becoming a framework of pore voids. The adsorptiondesorption isotherm of $\mathrm{Cr}$ oxide samples at partial pressures of P/Po 0.4-0.84 shows a large hysteresis loop owing to capillary condensation in the mesoporous channels and/or cages. The low-pressure portion of the isotherm indicated the existence of micropores (El-Sheikh et al. 2009b). The average pore diameter of samples heated at $400{ }^{\circ} \mathrm{C}$ was approximately 2-6 nm, as seen in Fig. 8b. Colmenares et al. (2014) reported that $\mathrm{Cr}_{2} \mathrm{O}_{3}$ was used as a photocatalyst for phenol degradation. The surface area of this photocatalyst material is about $5-10 \mathrm{~m}^{2} / \mathrm{g}$, when calcined from 180 to $600{ }^{\circ} \mathrm{C}$. From the above results, the prepared $\mathrm{Cr}$ oxide should be a promising adsorbent and photocatalyst, especially as the material has nanosize dimensions, a mesoporous structure and a higher surface area (about $30 \mathrm{~m}^{2} \mathrm{~g}^{-1}$ ) than that reported by Colmenares et al. (2014).

\section{Thermal behavior}

The DTA and TGA data for $\mathrm{Cr}_{2} \mathrm{O}_{3}$ nanoparticles are graphically represented in Fig. 9. A weight loss is evident by the endothermic peak at $163{ }^{\circ} \mathrm{C}$. The peak may be assigned to the release of hydroscopic water molecules (ElSheikh et al. 2009a). However, heating $\mathrm{Cr}$ hydroxide samples to temperatures of $300-500{ }^{\circ} \mathrm{C}$ shows an exothermic peak at $433{ }^{\circ} \mathrm{C}$ corresponding to additional weight loss. This peak could be assigned to the decomposition of $\mathrm{CrO}_{3}$ into $\mathrm{Cr}_{2} \mathrm{O}_{3}$ with oxygen liberation (Lime et al. 2006), which is consistent with XRD data:

$4 \mathrm{CrO}_{3} \rightarrow \mathrm{CrO}_{3}+1 \frac{1}{2} \mathrm{O}_{2}$

\section{Hypothetical model for the formation mechanism}

The tannery waste solution contains metal ions such as $\mathrm{Cr}$, $\mathrm{Ca}$ and $\mathrm{Mg}$. It is, therefore, reasonable to separate the elements before disposal or recycling of the tannery waste effluent. This study aimed to use $\mathrm{Ca}$ and $\mathrm{Cr}$ ions for synthesis of $\mathrm{Ca}$ oxalate or sulfate and $\mathrm{Cr}$ oxide nanoparticles, respectively.

The element $\mathrm{Cr}$ has a body-centered cubic crystal structure with an atomic structure $[\mathrm{Ar}] 3 \mathrm{~d}^{5} 4 \mathrm{~s}^{1}$. The metal can exhibit a wide range of possible oxidation states in chemical compounds with the +3 and +6 states being the most common and with the former being the more stable energetically; compounds with oxidation states $+1,+4$ and +5 are rare. Like molybdenum, tungsten and rhenium, $\mathrm{Cr}$ has a special ability to form a quintuple bond, also known as a fivefold bond, which was first discovered in 2005. In $\mathrm{Cr}$ compounds, di-Cr was found to have a quintuple bond, 

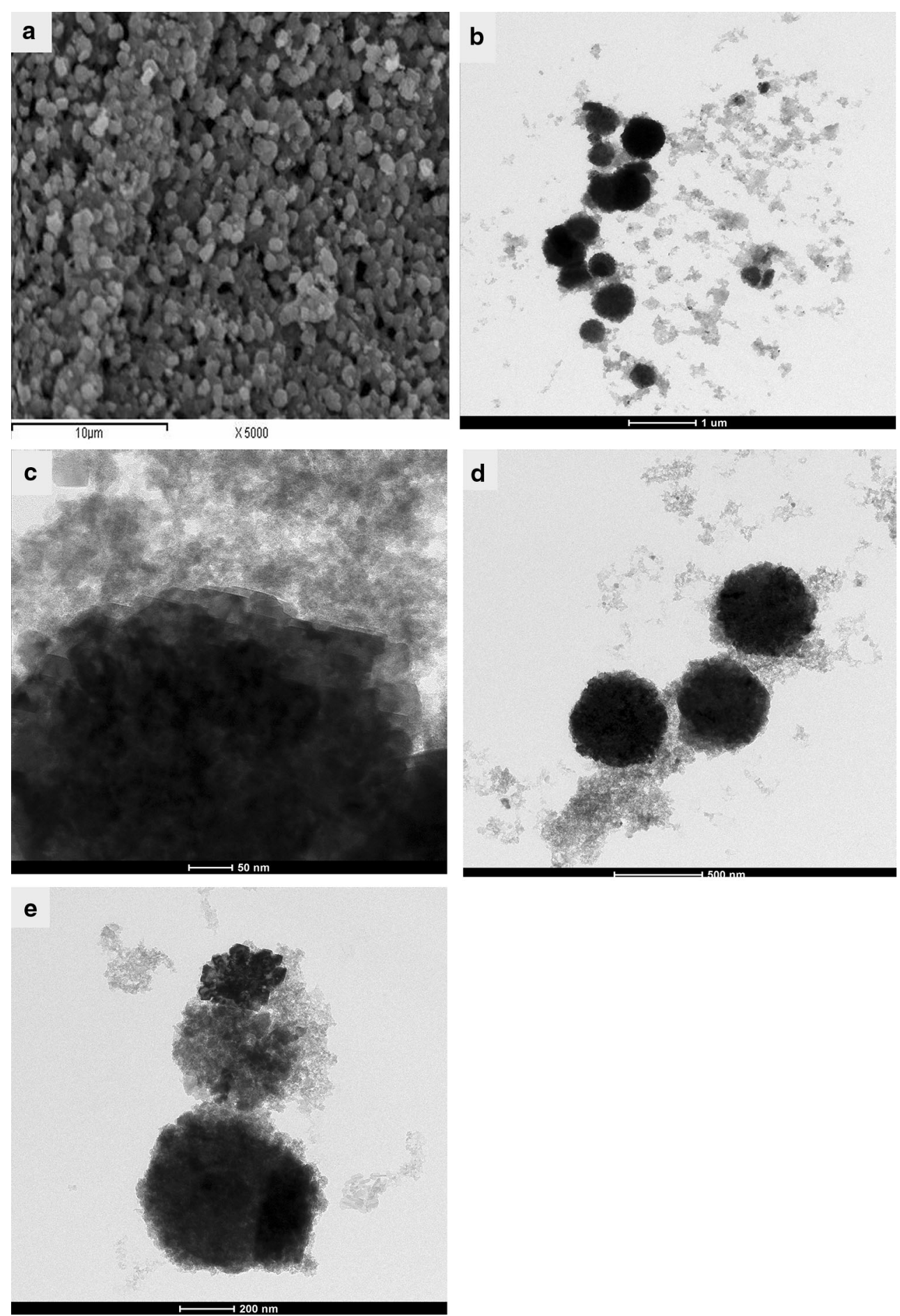

Fig. 7 a Micrographs of the chromium oxide mesospheres after heating at $500{ }^{\circ} \mathbf{C}$. b-e TEM images for $\mathrm{Cr}_{2} \mathrm{O}_{3}$ samples heated at 400 and $500{ }^{\circ} \mathrm{C}$

which means that 10 electrons are participating in the metal-to-metal bond. Chromium uses a terphenyl ligand to perform this action, thus making it relatively weak, but stable up to $200{ }^{\circ} \mathrm{C}$. A quintuple bond is only possible if a $\mathrm{Cr}$ atom has only one other ligand to maintain bond stability. Although the discovery is fairly recent, it has already provided great insight into how transition metals are able to bond with each other (Greenwood et al. 1997). In terms of chemical properties, $\mathrm{Cr}$ hydroxide particles are amphoteric. With $\mathrm{Cr}$ hydroxide, three $(\mathrm{OH})^{-1}$ groups replace three hydronium molecules around the $\mathrm{Cr}$ atom to form the following configuration (Cañizares et al. 2006): 

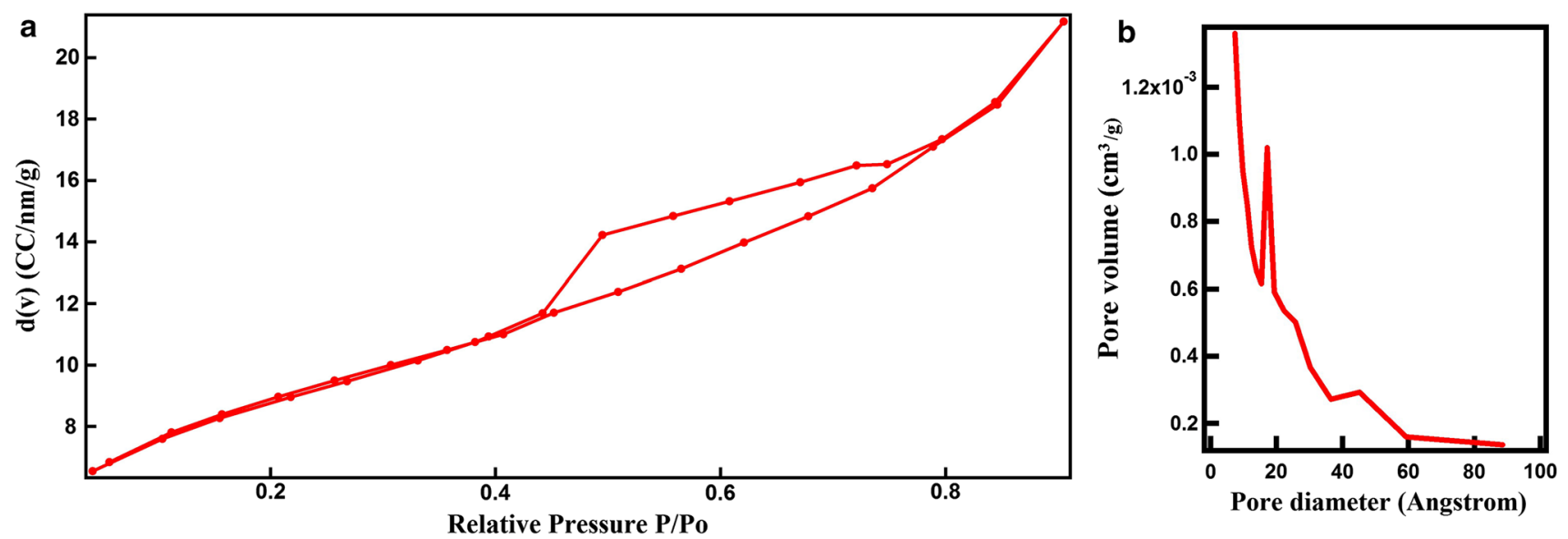

Fig. 8 a-b Nitrogen adsorption-desorption isotherm and pore size distribution for $\mathrm{Cr}_{2} \mathrm{O}_{3}$ nanoparticles (sample heated at $400{ }^{\circ} \mathrm{C}$ )

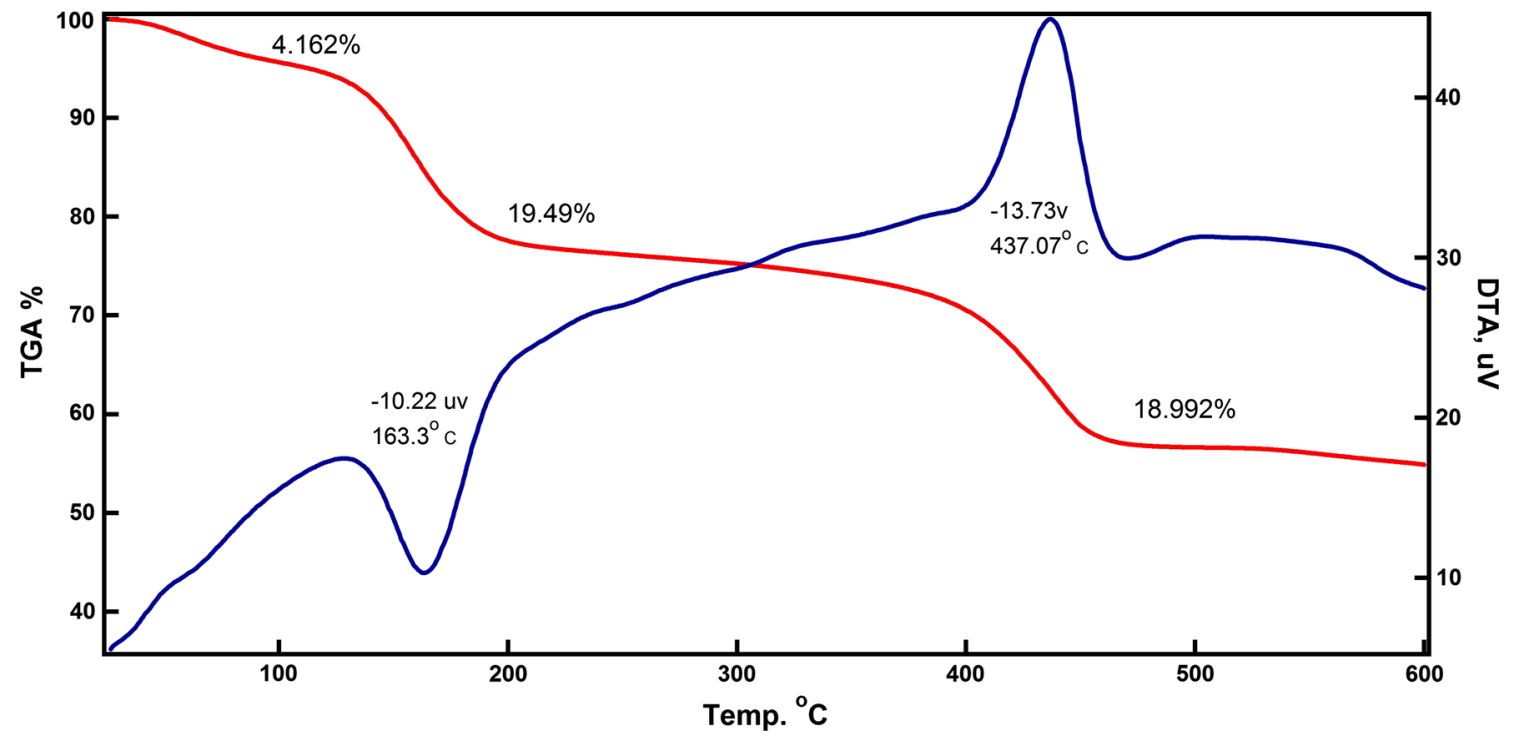

Fig. 9 TGA and DTA plots for $\mathrm{Cr}_{2} \mathrm{O}_{3}$ nanoparticles

$$
\begin{aligned}
{\left[\mathrm{Cr}\left(\mathrm{H}_{2} \mathrm{O}\right)_{6}\right]_{(\mathrm{aq})}^{3+}+3 \mathrm{OH}_{(\mathrm{aq})}^{-}==} & >\left[\mathrm{Cr}(\mathrm{OH})_{3}\left(\mathrm{H}_{2} \mathrm{O}\right)_{3}\right]_{(\mathrm{s})} \\
& +3 \mathrm{H}_{2} \mathrm{O}_{(1)}
\end{aligned}
$$

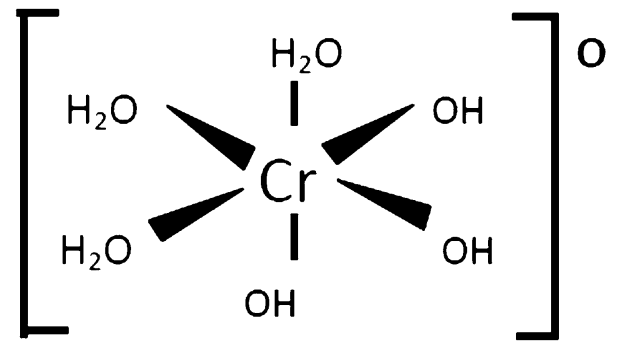

Water molecules establish a water film, which coats the $\mathrm{Cr}$ hydroxide molecule. When precipitated, $\mathrm{Cr}$ hydroxide molecules co-link together by weak adhesion forces under the surface tension action of the water coating. A nucleus for particle formation is thus initiated. Particle propagation takes place with a progressive weakness occurring in the adhesion forces of the particles so that they attain optimum size. Particles are not agglomerated on filtration hence can form a highly spongy gel-like structure. Heating this structure up to $400{ }^{\circ} \mathrm{C}$ involves degradation of the hydrated water, and $\mathrm{Cr}(\mathrm{OH})_{3}$ decomposes to different forms of $\mathrm{Cr}$ oxide. It is worth noting that the $\mathrm{Cr}$ hydroxide precipitate produces nanoparticles of spongy amorphous $\mathrm{Cr}$ oxide when heated at $300{ }^{\circ} \mathrm{C}$, which crystallizes upon further heating at $400{ }^{\circ} \mathrm{C}$.

\section{Conclusion}

Chromium-rich effluent, generated from the leather tanning process was studied as a potential feedstock for generating $\mathrm{Cr}$ oxide nanoparticles. Preliminary separation of $\mathrm{Ca}$ and $\mathrm{Cr}$ ions in the waste effluent aided the synthesis of $\mathrm{Ca}$ 
oxalate and mesosphere $\mathrm{Cr}$ oxide nanoparticles. The physicochemical characteristics of the nanomaterial depended on the preparation conditions and parameters such as sample $\mathrm{pH}$, heating temperature and time. The final product consisted of mesospheres built up from smaller nanoparticles. The smaller nanoparticles possess a large specific surface area and would constitute active centers suitable for catalyzation of microspheres. Results are explained on the premise that $\mathrm{Cr}$ metal has a special ability to form a quintuple bond. Heating such structures up to $400{ }^{\circ} \mathrm{C}$ involves degradation of the hydrated water, and the $\mathrm{Cr}(\mathrm{OH})_{3}$ decomposes to $\mathrm{Cr}$ oxides of differing valences. The trivalent $\mathrm{Cr}$ oxide species, at $500{ }^{\circ} \mathrm{C}$, has a mesoporous structure and a mesosphere shape. A mechanism for the formation of the spongy structure of the $\mathrm{Cr}$ oxide nanoparticles was proposed. It is of interest to note that the water remaining after removal of $\mathrm{Ca}$ and $\mathrm{Cr}$ ions was found to be suitable for recycling in the tannery process.

Acknowledgments The authors would like to thank the Central Metallurgical Research \& Development Institute, Egypt, for financial support for this research (Grant No 954/D.M/2012).

\section{References}

Abreu MA, Toffoli SM (2009) Characterization of a chromium-rich tannery waste and its potential use in ceramics. Ceram Int 35:2225-2234. doi:10.1016/j.ceramint.2008.12.011

Brunauer S, Emmett PH, Teller E (1938) Adsorption of gases in multimolecular layers. J Am Chem Soc 60:309. doi:10.1021/ ja01269a023

Beckhoff B, Kanngießer B, Langhoff N, Wedell R, Wolff H (2006) Handbook of practical X-ray fluorescence analysis, Springer, ISBN 3-540-28603-9

Cañizares P, Martínez F, Jiménez C, Lobato J, Rodrigo MA (2006) Comparison of the aluminum speciation in chemical and electrochemical dosing processes. Ind Eng Chem Res 45:8749-8756. doi:10.1021/ie060824a

Coats AW, Redfern JP (1963) Thermogravimetric analysis: a review. Analyst 88:906-924. doi:10.1039/AN9638800906

Colmenares JC, Lisowski P, Jose MB, Cot J, Rafael L (2014) Unprecedented photocatalytic activity of carbonized leather skin residues containing chromium oxide phases. Appl Catal B Environ 150-151:432-437. doi:10.1016/j.apcatb.2013.12.038

El-Sheikh SM, Rabbah M (2013) Novel low temperature synthesis of spinel nano-magnesium chromites from secondary resources. Thermochim Acta 568(20):13-19. doi:10.1016/j.tca.2013.06.024

El-Sheikh SM, Harraz FA, Abdel-Halim KS (2009a) Catalytic performance of nanostructured iron oxides synthesized by thermal decomposition technique. J Alloys Compd 487:716-723. doi:10.1016/j.jallcom.2009.08.053

El-Sheikh SM, Mohamed RM, Fouad OA (2009b) Synthesis and structure screening of nanostructured chromium oxide powders. J Alloys Compd 482:302-307. doi:10.1016/j.jallcom.2009.04.011

Gebrehawaria G, Hussen A, Rao VM (2014) Removal of hexavalent chromium from aqueous solutions using barks of Acacia albida and leaves of Euclea schimperi. Int $\mathrm{J}$ Environ Sci Technol. doi:10.1007/s13762-014-0530-2

Greenwood NN, Earnshaw A (1997) Chemistry of the elements, 2nd edn. Butterworth-Heinemann, New York, ISBN 0080379419
Gupta RK, Mitchell E, Candler J, Kahol PK, Ghosh K, Dong L (2014) Facile synthesis and characterization of nanostructured chromium oxide. Powder Technol 254:78-81. doi:10.1016/j.powtec. 2014.01.014

International Union of Leather Technologists and Chemists Societies (IULTCS), IUE (2004) Assessment for chromium containing waste from the leather industry. In: International Union of Environment IUE, pp 1-4. http://www.iultcs.org/environment.asp

Jiao C, Cheng Y, Fan W, Li J (2014) Synthesis of agar-stabilized nanoscale zero-valent iron particles and removal study of hexavalent chromium. Int J Environ Sci Technol. doi:10.1007/s13762-014-0524-0

Kabir G, Ogbeide SE (2008) Removal of chromate in trace concentration using ion exchange from tannery wastewater. Int J Environ Res 2(4):377-384

Kanagaraj J, Babu NKC, Mandal AB (2008) Recovery and reuse of chromium from chrome tanning waste water aiming towards zero discharge of pollution. J Clean Prod 16:1807-1813. doi:10. 4172/2155-6199.1000107

Kilic E, Fontb J, Puigb R, Olakc SC, Elik DC (2011) Chromium recovery from tannery sludge with saponin and oxidative remediation. J Hazard Mater 185:456-462. doi:10.1016/j.jhazmat.2010.09.054

Lime MD, Bonadimann R, de Andrade MJ, Toniolo JC, Bergmann $\mathrm{CP}$ (2006) Nanocrystalline $\mathrm{Cr}_{2} \mathrm{O}_{3}$ and amorphous $\mathrm{CrO}_{3}$ produced by solution combustion synthesis. $\mathrm{J}$ Euro Ceram Soc 26:1213-1220. doi:10.1016/j.jeurceramsoc.2005.01.042

Ludvik J (2004) Chrome balance in leather processing, United Nations industrial development organization, US/RAS/92/120/ 11-51, Regional programme for pollution control in the tanning industry in south-east Asia, Report pp 1-18

Macchi G, Pagano M, Pettine M, Santori M, Tiravanti G (1991) A bench study on chromium recovery from tannery sludge. Wat Res 25:1019-1026. doi:10.1016/0043-1354(91)90152-G

Ortega LM, Lebrunb R, Nöelc IM, Hausler R (2005) Application of nanofiltration in the recovery of chromium (III) from tannery effluents. J Sep Purif Technol 44:45-52. doi:10.1016/j.seppur. 2004.12.002

Patterson A (1939) The Scherrer Formula for X-Ray Particle Size Determination. Phys Rev 56:978-982

Scherrer P (1918) eund der Inneren Struktur von Röntgenstrahlen, Bestimmung der Gröss Kolloidteilchen Mittels Nachrichten von der Gesellschaft der Wissenschaften, Göttingen”. MathematischPhysikalische Klasse 2:98-100

Song Z, Williams CJ, Edyvean RGJ (2004) Treatment of tannery wastewater by chemical coagulation. Desalination 164:249-259. doi:10.1016/S0011-9164(04)00193-6

Sumathi KMS, Mahimairaja S, Naidu R (2005) Use of low-cost biological wastes and vermiculite for removal of chromium from tannery effluent. Bioresour Technol 96:309-316. doi:10.1016/j. biortech.2004.04.015

Tahir SS, Naseem R (2007) Removal of Cr(III) from tannery wastewater by adsorption onto bentonite clay. Sep Purif Technol 53:312-321. doi:10.1016/j.seppur.2006.08.008

Terzyk AP, Wloch J, Furmaniak S, Kowalczyk P, Harris PJF, Rychlicki G, Gauden PA (2007) How realistic is the pore size distribution calculated from adsorption isotherms if activated carbon is composed of fullerene-like fragments? Phys Chem Chem Phys 9:5919-5927

Williams DB, Carter CB (1996) Transmission electron microscopy: a textbook for materials science, Volume 2. Springer. p. 559. ISBN 0-306-45324-X

Zhou S, Zhou LX, Wang SM, Fang D (2006) Removal of Cr from tannery sludge by bioleaching method. J Environ Sci 18:885-890. doi:10.1016/S1001-0742(06)60009-0

Zhu LUZ, Yao X, Lu G, Yan Z (2008) Synthesis and characterization of chromium oxide nanocrystals via solid thermal decomposition at low temperature. Microporous Mesoporous Mater 112:621-626. doi:10.1016/j.micromeso.2007.10.044 